\title{
Trophic ecology of Mugil liza at the southern limit of its distribution (Buenos Aires, Argentina)
}

\author{
Gustavo Thompson ${ }^{1, *}$, Roberta Callico Fortunato ${ }^{1}$, Ignacio Chiesa ${ }^{2}$, Alejandra Volpedo ${ }^{1}$
}

\author{
${ }^{1}$ Instituto de Investigaciones en Producción Animal, Facultad de Ciencias Veterinarias, Universidad de Buenos Aires - INPA (CONICET-UBA) \\ (Av. Chorroarin 280. CABA, Buenos Aires, Argentina) \\ ${ }^{2}$ Museo Argentino de Ciencias Naturales "Bernardino Rivadavia" (CONICET) \\ (Buenos Aires, Argentina) \\ *Corresponding author: gustavo@ege.fcen.uba.ar
}

Financial Support: Universidad de Buenos Aires, UBACYT 20620110100007 Agencia Nacional de Promoción Científica y Tecnológica, PICT BICENTENARIO PICT № 2010-1372 CONICET, PIP 11220120100479CO

\section{ABSTRACT}

In order to get to know the habitat and feeding habits of Mugil liza on the southern coast of Buenos Aires province, 65 specimens obtained at two sampling sites - the San Blas bay (SBB) and the mouth of the Quequén-Salado river (QSR) - during spring (November 2012) and summer (February 2013) were analyzed. Specimens were measured, sexed and weighed, their stomachs were removed and their stomach contents weighed and analyzed under the stereoscopic microscope. The specimens were adults, 28-49 $\mathrm{cm}$ in length and weighing 380-1100 g. Population growth was higher in the SBB (TW: $0.003 * \mathrm{TL} 3.36$ ), than in RQS (TW: $0.045^{*}$ TL2.61). About $98 \%$ of the stomachs had some content, their repletion rate being of between 0.4 and $1.2 \%$. About $75 \%$ of the stomachs contained very fine sand with few benthic organisms (algae, copepods, foraminifera), whereas the remaining $25 \%$ of stomachs contained coarse sand and a greater presence of benthic fauna (amphipods, bivalves, gastropods and coral organisms). The linear relationship between the weight of stomach contents and the total weight and length of the fish showed that the rates of growth (slope) were the same at both sites, but intercept values were significantly higher for San Blas bay (test parallelism; $p<$ 0.001).

Descriptors: Mugil liza, Diet, Organic matter, Sediments.

\section{RESUMo}

Para conhecer o habitat e os hábitos alimentares de Mugil liza na costa sul de Buenos Aires, 65 exemplares obtidos durante a primavera (novembro de 2012) e o verão (fevereiro de 2013) foram analisados em duas áreas de amostragem: na Baía San Blas (SBB) e na foz do rio Quequén-Salado (QSR). Os exemplares foram medidos, pesados, o sexo foi identificado, os estômagos foram removidos e os conteúdos estomacais pesados e analisados sob estereomicroscópio. Os espécimes de $M$. liza eram adultos com comprimentos entre $28-49 \mathrm{~cm}$ e pesos entre 380-1100 g. O crescimento populacional foi maior na SBB (TW: $0,003 *$ TLx3,36), do que na QSR (TW: $0,045^{*} \mathrm{TL}^{\wedge} 2,61$ ). Em 98\% dos estômagos, havia conteúdo estomacal e o índice de repleção variou entre 0,4 e $1,2 \%$. Um total de $75 \%$ dos conteúdos estomacais foi composto de areia muito fina, com pouca presença de organismos bentônicos (algas, copépodas, foraminíferos), enquanto que em $25 \%$ dos estômagos havia areia grossa, com um aumento da presença de organismos da fauna bentônica (anfípodas, bivalves, gastrópodes e corais). As relações lineares entre o peso do conteúdo estomacal e o peso total e comprimento do peixe mostraram que as taxas de crescimento (inclinação) foram as mesmas em ambas as áreas de amostragem, mas os valores do intercepto foram significativamente maiores na Baía San Blas (teste $t ; p<0,001$ ).

Descritores: Mugil liza, Dieta, Matéria orgânica, Sedimentos. 


\section{INTRODUCTION}

Mugil liza is a species found in the coastal waters extending from Rio de Janeiro (Brazil) to Argentina, being most common in the South of São Paulo State and in estuarine regions of Lagoa dos Patos, Río de La Plata, Samborombón Bay and Mar Chiquita (COUSSEAU et al., 2005; ACUÑA PLAVAN et al., 2010; FISCHER et al., 2011; LORENZO et al., 2011; GARBIN et al., 2014). The taxonomic status of $M$. liza has not yet been defined; FRAGA et al. (2007) suggest that M. liza and M. platanus should be treated as a single species and considered part of $M$. cephalus (a species of cosmopolitan distribution, WHITFIELD et al., 2012), because of the limited level of genetic divergence between the two species. DURAND et al. (2012) proposed the existence of the 'M. cephalus species complex' which would consist of up to 14 species, which already includes M. cephalus, M. liza, and M. platanus. On the other hand, HERAS et al. (2009) suggest that Mugil platanus and M. liza should be regarded as a single species closely related to but distinct from $M$. cephalus, while GONZALEZ CASTRO et al. (2008) noted that M. platanus (M. liza) differs from $M$. cephalus because of its mitochondrial ADN, morphometric and meristic characters.

Information on the life history of the Mugillidae family is available only at the local level, there being no global view (WHITFIELD et al., 2012); mullet larval stages feed on plankton in the marine environment and a month after they reach the postflexion larval stage they migrate to the coast; juvenile and sub-adult stages develop in estuarine waters and change their diet from planctophagous to detritivorous, feeding mainly on detritus and benthic microalgae (DE SILVA, 1980). Adults migrate to open water to spawn and complete their cycle, and evidence suggests that there are no changes in the diet with the increase in the size of the body.

Detritivorous fishes are considered to transform the environment they inhabit, so knowledge of their feeding habits and the interrelation of this species with the environment is essential for the management of this cross-border resource; however, feeding studies on the area of the distribution of $M$. liza (M. platanus) are very few. JEREZ; CHRISTIANSEN (1987) studied the stomach contents of 3 specimens from the Mar Chiquita lagoon, ACHA (1990) studied the diet of juveniles up to $60 \mathrm{~mm}$ SL in Samborombón Bay and Mar Chiquita estuary, while OLIVEIRA; SOARES (1996) recorded the diet of juveniles and adults of these mugillidae in Sao Paulo, Brazil.
The purpose of this study was to get to know the ecological habitat and feeding ecology of M. liza at the southern limit of its distributional range, covering San Blas bay and the mouth area of the Quequén-Salado river (on the south coast of Buenos Aires province, Argentina).

\section{MATERIAL AND METHODS}

Specimens of $M$. liza were obtained at two sampling sites - Quequén-Salado river and San Blas bay (Figure 1) - in spring (November 2012) and summer (February 2013) - using different fishing gear in each place. Specimens were measured (TL: total length in $\mathrm{mm}$ ), weighed (TW: total weight in g) and their maturation stage (juvenile, sub-adults and adults) determined by macroscopic description of the gonads, in accordance with ESPER et al. (2000, 2001), GONZALEZ CASTRO et al. (2009). The stomach was removed and opened longitudinally. The stomach content was weighed (SWC) and preserved in alcohol $80 \%$. Function TW: $a \cdot \mathrm{TL}^{\wedge} \mathrm{b}$ was used to obtain the weight-length relation at each sampling site and maturation stage was determined to detect significant growth stage (FROESE, 2006). The condition factor (k) was estimated by K: TW/TL3, following RICKER (1975). Functions SWC: $a \cdot \mathrm{TW}+b$ and SWC: $\mathrm{a} \cdot \mathrm{TL}+b$ were used to calculate the relationship of the stomach content's weight to the total weight and length. Parameters $a$ and $b$ of each equation were calculated using the generalized least squares method. In order to determine if there were significant differences between the two sampling sites, the coefficients $a$ and $b$ of each of the above relationships were compared (ZAR, 1999). The rate of stomach repletion was estimated according to ALBERTINI-BERHAUT (1974), where CR: SWC•100/TW. Possible differences in CR value between sampling sites and maturation stage were analyzed using a two-factor ANOVA. Due to the small number of specimens analyzed, maturation stages were grouped in two levels: juveniles and adults (sub-adults, females and males). Each stomach's contents were analyzed under the stereoscopic microscope $(40 \mathrm{x})$. The predominant texture of the sediments registered in the stomach was described according to the Wentworth scale (WENTWORTH, 1922) and benthic organisms were individualized and identified to the highest possible taxonomic level. In the case of the amphipods, which were the most abundant group, family and gender taxonomic level was determined whenever possible. By the traditional methods of diet analysis (HYNES, 1950; HYSLOP, 1980), only the percentage of 
occurrence could be estimated: $\% \mathrm{~F}:(\mathrm{Ni} / \mathrm{Nt}) \cdot 100$, where $\mathrm{Ni}$ is the number of stomachs in which the food item was found and $\mathrm{Nt}$ is the total number of stomachs. Percentage of number $(\% \mathrm{~N})$, volume $(\% \mathrm{~V})$, index of relative importance (IRI) and index of absolute importance (AI) could not be estimated since the food items would need to be physically discriminated (and their number, volume and weight estimated), which was impossible because of the presence of organic remains. The presence of total organic matter (\% dry weight) in the stomach content was estimated by the difference in weight between the dry weight of stomach contents, after being dried at $90^{\circ} \mathrm{C}$ for $72 \mathrm{~h}$ and the weight of the ash after the combustion of samples in a muffle furnace at $450^{\circ} \mathrm{C}$ for 24 hours (as modified by SARGENT et al., 1983). Possible differences in concentrations between sampling sites, maturation stages and sediment types were analyzed using a three-factor ANOVA.

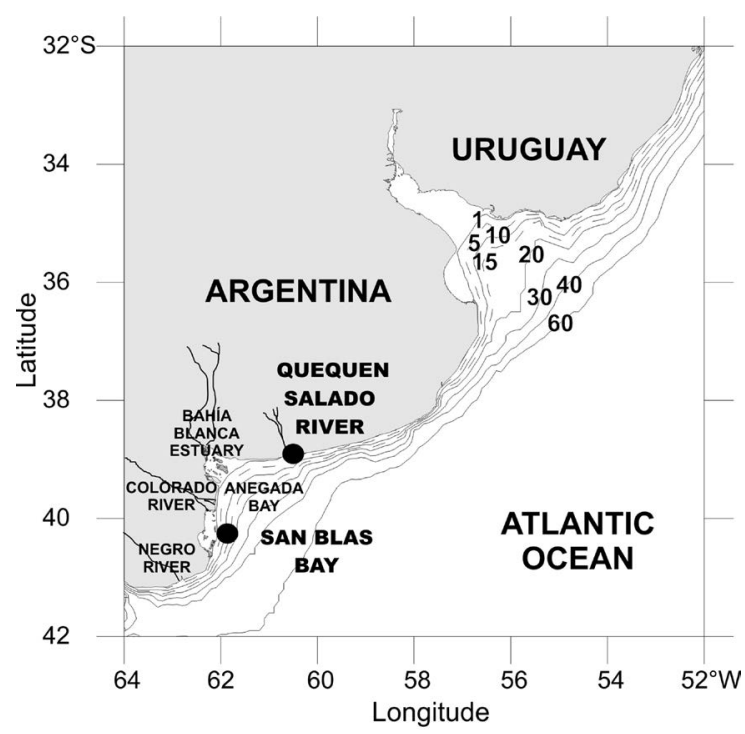

Figure 1. Geographical location of sampling sites, and main rivers in the area. Coastal bathymetry is also shown.

\section{RESULTS}

Size distribution was assessed for each season, site and maturity stage of a total of $65 \mathrm{M}$. liza specimens analyzed (Table 1). There were no significant differences between sites for total length and weight values. The rate of allometric increase (b) of the length - weight relationship, showed no significant difference as between juveniles and adults at either site (no growth stage) so data were pooled (Figure 2A), and $b$ was greater in San Blas bay (SBB) that in Quequén-Salado river (QSR), which implies greater total weight for similar size. The condition factor ranged from
0.88 to 1.28 , being similar in juveniles of both sites but significantly greater in adults in SBB than in RQS (Figure 2B). About $98 \%$ of the stomachs had some content. The stomach content weight of the spring samples was significantly lower than that of the summer ones in QSR (ANOVA, F1, 28:33.00 $p<0.001$ ), so only that the inter-site comparison of the summer samples was undertaken. The relationships between stomach content weight and total length and weight were significant $(0.001<p<0.028$; Figure 3,4$)$. The comparison of these functions between the two sampling sites showed that the rates of increase (slope) were the same (parallelism test $t ; p>0.13$ ) while the a (intercept) values were significantly higher in SBB that in QSR (parallelism test $t ; p<0.001$ ). The $a$ (intercept) parameter may be considered an indicator of good physiological condition in a population, given the conditions in a certain environment (PAULY, 1984). The index of stomach repletion showed values between 0.4 and $1.2 \%$, which indicates a predominance of half-filled stomachs. There is no significant difference between juveniles and adults and it is only slightly higher in SBB than in QSR (ANOVA F1.42:3.79 $p=05$ ), so $M$. liza incorporated somewhat more sediments in SBB than in the QSR. About 80\% (SBB) and 75\% (QSR) of stomach contents consisted of very fine sand, silt and clay with a slight presence of benthic organisms - which differed between sites and seasons $(\% \mathrm{~F}<11 \%$, copepods, foraminifera, algae, etc. Table 2). Over $38 \%$ of juveniles had food items in their stomach content with this type of sediment, while this happened to less than $11 \%$ of adults. In the rest of the specimens their stomachs presented mainly coarse sands and a greater presence of benthic fauna, which differed according to the sampling site $(\% \mathrm{~F}>40 \%$; Table 2$)$. All the juveniles analyzed with this type of sediments in their stomach content presented food items. Coral organisms and nematodes were recorded in the area of QSR. On the other hand, amphipods, bivalves and gastropod molluscs were found in individuals of the SBB area. Among the amphipod specimens of the family Corophiidae, Ampeliscidae, Phoxocephalidae, Lysianassidae, Ochlesidae and Aoridae were recorded. Most amphipods were in good condition and their concentration fluctuated between 4 and 67 individuals per stomach.

Content of total organic matter $(n=57)$ ranged from 2.7 to $7 \%$ and differed between the types of sediment that were recorded in the stomachs; their concentrations being significantly greater in the case of stomachs with sediments composed of very fine sand and silt than in the case of stomachs containing coarse sand. However, in these 
Table 1. Range of total length and number of $M$. liza specimens (n) analyzed by sampling area and season

\begin{tabular}{ccccc}
\hline & \multicolumn{4}{c}{ Total length range (mm) } \\
& J & SA & F & M \\
\hline RQS - SP & $285-407(12)$ & $416(1)$ & $449-457(2)$ & $438(1)$ \\
RQS - SU & $315-381(12)$ & $404-433(5)$ & $440-482(2)$ & $440-485(3)$ \\
SBB - SU & $388-419(9)$ & $391-434(14)$ & $434-463(4)$ & - \\
\hline
\end{tabular}

RQS: Quequén-Salado river; SBB: San Blas Bay; SP: Spring; SU: Summer; J: Juvenile; SA: Sub-adult; F: Female; M: Male.

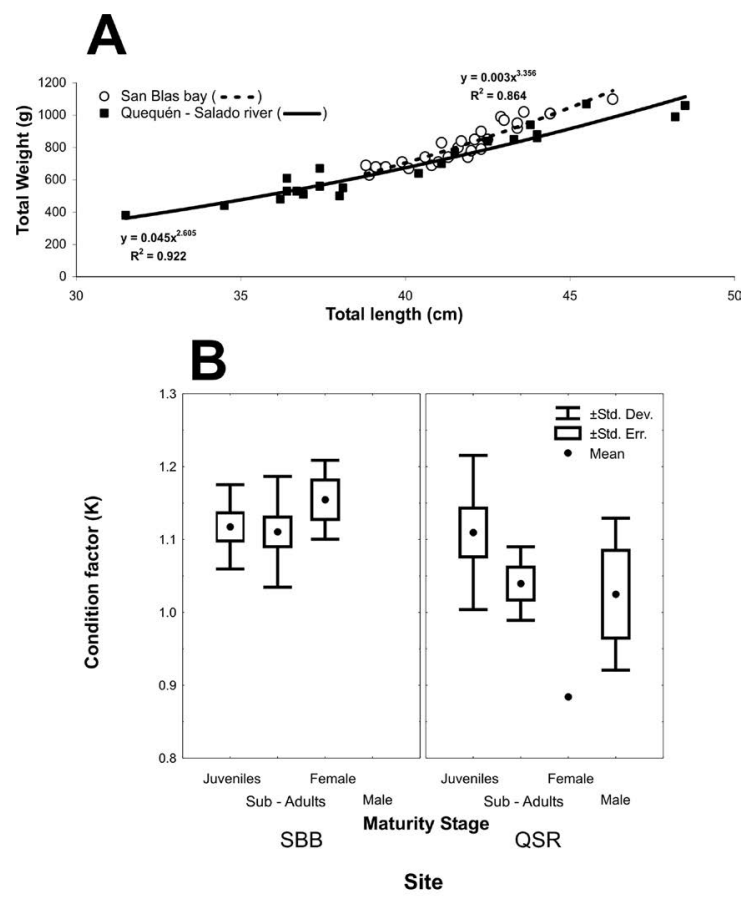

Figure 2. A. Total weight to total length relationship for Mugil liza specimens in both sampling areas. B. Condition factor $(\mathrm{k})$ for each maturation stage at both sites. RQS: Quequén-Salado river; SBB: San Blas bay.

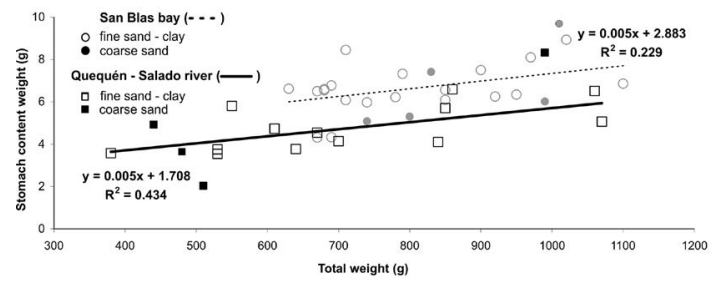

Figure 3. Total stomach content to total weight relationship for Mugil liza specimens in both sampling sites. Trendlines and linear equation are shown. Black dots indicate stomach content with coarse sand sediment type and white dots content with very fine sand-clay sediment type. latter one there was a greater percentage of total organic matter in the food due to the presence of benthic organisms, mainly amphipods (Table 2). In the case of fine sand and silty sediments, the total amount of organic matter in the stomach content was significantly higher in SBB than in QSR (3-way ANOVA, F1.39:5.46, P:0.02) and higher in adults than in juveniles (3-way ANOVA, F1.39:5.59, $p=0.02$ ) (Figure 5). This result is in agreement with the higher weight to total length relationship and higher condition factor determined for SBB specimens.

\section{DISCUSSION}

Mugil liza showed differences in its trophic ecology at the southern limit of its distributional range. The northern site of the study area presented fine (silty-clay type) sediments that were provided by the Quequén-Salado river (CARBONE et al., 2005). Sediment mean size decreases upstream by virtue of the high energy conditions prevailing near the mouth of the river (wave activity, strong currents and tidal action; WRIGHT, 1968; PICCOLO; PERILLO, 1999). On the other hand, large concentrations of silt-clay are found in the coastal region at the southern site between Bahia Blanca and San Blas Bay, known as Anegada Bay (Figure 1), due to the contribution of the Colorado River and Bahia Blanca estuary, while coarse sediments were located between the Negro River mouth and San Blas Bay, since this area is affected by an intense coastal drift from the southern region (ALIOTTA et al., 1999). The hydrological dynamics of the study area often create a potential retention area which displays an average top-to-bottom integrated anticlockwise gyre (PIOLA \& RIVAS, 1997; PALMA et al., 2008). These environmental

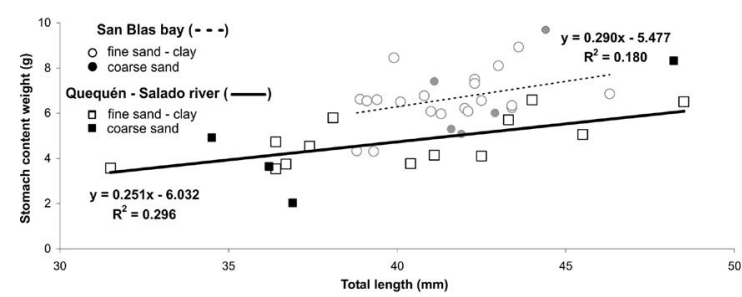

Figure 4. Total stomach content to total length relationship for Mugil liza specimens at both sampling sites. Trendlines and linear equation are shown. Black dots indicate stomach content with coarse sand sediment type and white dots content with very fine sand-clay sediment type. 
Table 2. Percentage occurrence of food items (\%) in $M$. liza stomach content, by sampling area, season, predominant sediment type

\begin{tabular}{|c|c|c|c|c|c|c|c|c|c|}
\hline & Gastropods & Foraminifers & Algae & Copepods & Ostracods & Bivalves & Amphipods & Nematodes & Coralline rests \\
\hline RQS-SP-FS & 8 & 8 & 8 & - & - & - & - & - & - \\
\hline RQS-SU-FS & 11 & - & - & 6 & 6 & 6 & - & - & - \\
\hline SBB-SU-FS & - & - & - & - & - & - & 5 & - & 5 \\
\hline RQS-SU-CS & - & - & - & - & - & - & - & 50 & 75 \\
\hline SBB-SU-CS & 40 & - & - & - & - & 40 & 80 & - & - \\
\hline
\end{tabular}

RQS: Quequén-Salado river; SBB: San Blas bay; SP: Spring; SU: Summer; FS: fine sand sediment type: CS: coarse sand sediment type.

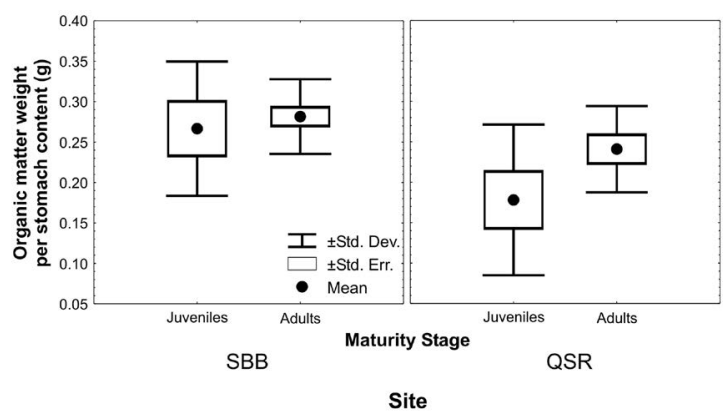

Figure 5. Percentage of organic matter contribution (mean, standard error) in stomach content of Mugil liza, by main sediment type in the stomach and sampling place: (QSR) Quequén-Salado river and (SBB) San Blas bay.

characteristics determined differences between the benthic communities, on which $M$. liza feeds, of the two sites (BREMEC; LASTA, 1998). These were reflected in the dissimilar benthic fauna registered in the stomach content of the southern (SBB) and northern (QSR) samples which were also dissimilar as regards the type of sediment found in the stomach content of M. liza at each site. The level of the taxonomic identification of benthic organisms in the food content did not permit a more specific comparison between sites. This is, however, the first study to show amphipods in the diet of $M$. liza, since previous reports on the stomach contents of $M$. liza indicate the presence of benthic diatoms and dinoflagellates together with copepods and other metazoa (OLIVEIRA; SOARES, 1996; JEREZ; CHRISTIANSEN, 1987).

Several papers have concluded that mugilids feed on microalgae, detritus, sediments and metazoa (ODUM \& HEALD, 1975; KING, 1988; OLIVEIRA; SOARES, 1996). Our results suggest that the diet of Mugil liza is based on organisms associated with fine sediments - both in the case of juveniles and adults. However, only 35\% of stomach contents showed some recognizable benthonic organism beyond the sediments, which points to the importance of the organic matter associated with the sediments. The importance of organic matter and detritus as food for mugilids has been described for the tropical estuarine habitats characterized by the presence of mangroves (OLIVEIRA; SOARES, 1996). Detritus has a high energetic value due to the complex ecosystem that organic matter-bacteria-fungi-protozoa form as a single unit (ODUM; HEALD, 1975).

The differences in mean organic matter found in each type of stomach content and between sites suggest that $M$. liza uses different habitats, related to varied local depths. The high contribution of stomach content with fine sediments in both areas corroborated the preference of mugilids for a fine clay-silt rather than a coarser bottom (ODUM; HEALD, 1975). Fine sediment particles have organic matter absorbed or adsorbed, so the smaller the particle the larger is its relative food value (ODUM, 1968). RUBIO et al. (2000) found a good correlation between organic matter and fine-grained sediments in an environment in Spain; deeper waters were characterized by finer sediments because of low energy levels and higher values of organic matter, while shallow waters were characterized by coarse sediments and lower values of organic matter. CARRANZA-EDWARDS et al. (2005) found sandy (coarse) sediments (with less organic matter) near the coastline, and finer ones (with more plentiful organic matter) in deep waters, in Southern Mexico. Despite those authors, the contribution of organic matter registered in the sediments in this present study was among the lowest detected for the stomach content of mugilids [8-31\% for Mugil liza (ACHA, 1990); 5.9-9.8\% for Mugil cephalus (ODUM, 1970); 5-30\% for Chelon labrosus (HICKLING, 1970)]. The small contribution of organic matter in the sediments and lower condition factors than those described for northern populations of M. liza during summer (GARBIN et al., 2014) may be indicative of the nutritional condition of this species at the southern limit of its distributional range.

In order to analyze the diet selectivity of $M$. liza, further studies should include specimens with a wider range 
of total length, and simultaneous studies of local benthic fauna. In addition to and in the light of the importance of organic matter in the diet of $M$. liza and the presence of organic and inorganic toxic substances associated with sediments at the southern limit of its distribution (BOTTÉ et al., 2010; ROSSO et al., 2013), it is important that the intake and accumulation of these elements through the diet of $M$. liza should be analyzed. Our results show a different habitat-species relationship at the southern limit of the distributional range of M. liza and thus it is necessary to investigate other methods of study for the identification of different populations of $M$. liza on the Buenos Aires coast (applied parasite studies, genetics, otolith microchemistry, etc.).

\section{ACKNOWLEDGEMENTS}

The authors wish to thank the Universidad de Buenos Aires and the Agencia Nacional de Promoción Científica y Tecnológica for the funding received from UBACYT 20620110100007 and PICT BICENTENARIO PICT-2010-1372, respectively.

\section{REFERENCES}

ACHA, E. M. Estudio anatómico-ecológico de la lisa (Mugil liza) durante su primer año de vida. Frente Marit., v. 7, p. 37-43, 1990.

ACUÑA PLAVAN, A.; PASSADORE, C.; GIMÉNEZ, L. Fish assemblage in a temperate estuary on the uruguayan coast: seasonal variation and environmental influence. Braz. J. Oceanogr., v. 58, n. 4, p. 299-314, 2010.

ALBERTINI-BERHAUT, J. Biologie des stades juveniles de Teleosteens Mugilidae Mugil auratus Risso 1810, Mugil capito Cuvier 1829 et Mugil saliens Risso 1810. Aquaculture, v. 4, n. 2, p. 13-27, 1974.

ALIOTTA, S.; SPAGNUOLO, J. O.; GINSBERG, S. S.; GELÓS, E. M. Sedimentos de fondo-subfondo y aspectos geomorfológicos de la plataforma continental entre el estuario de Bahía Blanca y bahía Anegada, provincia de Buenos Aires. AAS Revista, v. 6, n. 1/2, p. 19-35, 1999.

BOTTÉ, S. E.; FREIJE, R. H.; MARCOVECCHIO, J. E. Distribution of several heavy metals in tidal flats sediments within Bahia Blanca Estuary (Argentina). Water. Air Soil Pollut., v. 210, n.1/4, p. 371-388, 2010.

BREMEC, C.; LASTA, M. Mapeo sinóptico del macrobentos asociados a la dieta en fondos de alimentación de la corvina rubia Micropogonias furnieri en el área de El Rincón, Noviembre, 1994. INIDEP Inf. Tec., v. 21, p. 117-132, 1998.

CARBONE, M. E.; PICCOLO, M. C.; PERILlO, G. M. Morphology and physical parameters of the Claromecó Creek Estuary, Argentina. An. Inter. J. Mar. Sci., v. 21, n. 2, p. 55-63, 2005 .
CARRANZA-EDWARDS, A.; ROSALES-HOZ, L.; URRUTIA-FUCUGAUCHI, J.; SANDOVAL-FORTANEL, A.; MORALES DE LA GARZA, E.; LOZANO SANTA CRUZ, R. Geochemical distribution pattern of sediments in an active continental shelf in Southern Mexico. Cont. Shelf Res., v. 25, n. 4, p. 521-537, 2005.

COUSSEAU, M. B.; GONZÁlEZ CASTRO, M.; FIGUEROA, D. E.; GOSZTONYI, A. E. Está presente Mugil liza Valenciennes 1836 (Teleostei: Mugiliformes) en aguas argentinas? Rev. Biol. Mar. Oceanogr., v. 40, n. 2, p. 133-140, 2005.

DE SILVA, S. S. Biology of juvenile grey mullet: a short review. Aquaculture, v. 19, n. 1, p. 21-36, 1980.

DURAND, J. D.; CHEN, W. J.; SHEN, K. N.; FU, C.; BORSA, P. Genus-level taxonomic changes implied by the mitochondrial phylogeny of grey mullets (Teleostei: Mugilidae). C. R. Biologies, v. 335, n. 10, p. 687-697, 2012.

ESPER, M. D. L. P.; DE MENEZES, M. S.; ESPER, W. Escala de desenvolvimento gonadal e tamanho de primeira maturação de fêmeas de Mugil platanus Günther, 1880 da Baía de Paranaguá, Paraná, Brasil. Acta Biol. Par., v. 29, p. 255-263, 2000.

ESPER, M. D. L. P.; DE MENEZES, M. S.; ESPER, W. Época reprodutiva de Mugil platanus (Günther, 1880), Pisces Mugilidae da Baia de Paranaguá (Paraná, Brasil). Acta Biol. Par., v. 30, p. $5-17,2001$.

FISCHER, L. G.; PEREIRA, L. E. D.; VIEIRA, J. P. Peixes estuarinos e costeiros. 2nd ed. Rio Grande: Pallotti, 2011.

FRAGA, E.; SCHNEIDER, H.; NIRCHIO, M.; SANTA-BRIGIDA, E.; RODRIGUES-FILHO, L. F.; SAMPAIO, I. Molecular phylogenetic analyses of mullets (Mugilidae, Mugiliformes) based on two mitochondrial genes. J. Appl. Ichthyol., v. 23, n. 5, p. 598-604, 2007.

FROESE, R. Cube law, condition factor and weight-length relationships: history, meta-analysis and recommendations. J. Appl. Ichthyol., v. 22, n. 4, p. 241-253, 2006.

GARBIN, T.; CASTELLO, J. P.; KINAS, P. G. Age, growth, and mortality of the mullet Mugil liza in Brazil's southern and southeastern coastal regions. Fish. Res., v. 149, p. 61-68, 2014.

GONZÁlEZ CASTRO, M.; HERAS, S.; COUSSEAU, M. B.; ROLDÁN, M. I. Assessing species validity of Mugil platanus Günther, 1880 in relation to Mugil cephalus Linnaeus, 1758 (Actinopterygii). Ital. J. Zool., v. 75, n. 3, p. 319-325, 2008.

GONZÁlEZ CASTRO, M.; ABACHIAN, V.; PERROTTA, R. G. Age and growth of the striped mullet, Mugil platanus (Actinopterygii, Mugilidae), in a southwestern Atlantic coastal lagoon $\left(37^{\circ} 32^{\prime} \mathrm{S}-57^{\circ} 19 \mathrm{~W}\right)$ : a proposal for a life-history model. J. Appl. Ichthyol., v. 25, n. 1, p. 61-66, $2009 \mathrm{~b}$.

HERAS, S.; ROLDÁN, M. I.; CASTRO, M. G. Molecular phylogeny of Mugilidae fishes revised. Rev. Fish. Biol. Fish., v. 19, n. 2, p. 217-231, 2009.

HICKLING, C. F. A contribution to the natural history of the english grey mullets [Pisces, Mugilidae]. J. Mar. Biol. Ass. UK., v. 50, n. 3, p. 609-633, 1970.

HYNES, H. B. N. The food of fresh-water sticklebacks (Gasterosteus aculeatus and Pygosteus pungitius), with a review of methods used in studies of the food of fishes. J. Anim. Ecol., v. 19, p. 36-58, 1950.

HYSLOP, E. J. Stomach contents analysis: a review of methods and their application. J. Fish Biol., v. 17, n. 4, p. 411-429, 1980. 
JEREZ, B.; CHRISTIANSEN, H. E. Estudio anatómico e histológico del sistema digestivo de la lisa (Mugil liza) de la laguna Mar Chiquita, y breve comentario sobre su alimentación. Publ. Com. Téc. Mix. Fr. Mar., v. 3, p. 7991, 1987.

KING, R. P. New observations on the trophic ecology of Liza grandisquamis (Valenciennes, 1836) (Pisces: Mugilidae) in the Bonny river, Niger Delta, Nigeria. Cybium, v. 12, n. 1, p. 23-36, 1988.

LORENZO, M. I.; ASTARLOA, J. M.; NORBIS, W.; COUSSEAU, M. B. Long term fish assemblages as units of management in a temperate estuary (Rio de la Plata-SW Atlantic Ocean). Braz. J. Oceanogr., v. 59, n. 1, p. 43-59, 2011.

ODUM, W. E. The ecological significance of fine particle selection by the striped mullet Mugil cephalus. Limnol. Oceanogr., v. 13, n. 1, p. 92-98, 1968.

ODUM, W. E. Utilisation of the direct grazing and plant detritus food chains by the striped mullet Mugil cephalus. In: STEELE J. H. (Ed.). Marine food chains. Berkeley \& Los Angeles: University of California Press, 1970. p. 222-240.

ODUM, W. E.; HEALD, E. J. The detritus-based food web of an estuarine mangrove community. In: CRONIN, L. E. (Ed.). Estuarine, Research. New York: Academic Press, 1975. p. 265-286.

OLIVEIRA, I.; SOARES, L. Alimentacao da tainha Mugil platanus Günther, 1880 (Pisces: Mugilidae), da região estuarino-lagunar de Cananéia, São Paulo, Brasil. Bol. Inst. Pesca., v. 23, p. 95-104, 1996.

PALMA, E. D.; MATANO, R. P.; PIOLA, A. R. A numerical study of the Southwestern Atlantic Shelf circulation: Stratified ocean response to local and offshore forcing. J. Geophys. Res., v. 113, p. 1-22, 2008.

PAULY, D. Fish population dynamics in tropical waters: a manual for the use with programmable calculators. Penang: ICLARM, Studies and Reviews, 1984.
PICCOLO, M. C.; PERILlO, G. M. The Argentina estuaries: a review. In: PERRILLO G. M.; PICCOLO, M.C.; PINO-QUIVARA, M. (Eds.). Estuaries of South America. Berlin, Heidelberg: Springer, 1999. p. 101-132.

PIOLA, A. R.; RIVAS, A. L. Corrientes en la plataforma continental. In: Boschi, E. E. (Ed.). El Mar Argentino y sus recursos pesqueros. Tomo 1: Antecedentes históricos de las explotaciones en el mar y las características ambientales. Mar del Plata: INIDEP, 1997. p. 119-132.

RICKER, W. E. Computation and interpretation of biological statistics of fish populations. Bull. Fish. Res. Board Can., v. 191, p. 382, 1975.

ROSSO, J. J.; SCHENONE, N. F.; CARRERA, A. P.; CIRELLI, A. F. Concentration of arsenic in water, sediments and fish species from naturally contaminated rivers. Environ. Geochem. Health, v. 35, n. 2, p. 201-214, 2013.

RUBIO, B.; NOMBELA, M. A.; VILAS, F. Geochemistry of major and trace elements in sediments of the Ria de Vigo (NW Spain): an assessment of metal pollution. Mar. Pollut. Bull., v. 40, n. 11, p. $968-980,2000$.

SARGENT, J. R.; HOPKINS, C. C. E.; SEIRING, J. V.; YOUNGSON, A. Partial characterization of organic material in surface sediments from Balsfjorden, northern Norway, in relation to its origin and nutritional value for sediment-ingesting animals. Mar. Biol., v. 76, n. 1, p. 87-94, 1983.

WENTWORTH, C. K. A scale of grade and class terms for clastic sediments. J. Geol., v. 30, n. 5, p. 377-392, 1922.

WHITFIELD, A. K.; PANFILI, J.; DURAND, J. D. A global review of the cosmopolitan flathead mullet Mugil cephalus Linnaeus 1758 (Teleostei: Mugilidae), with emphasis on the biology, genetics, ecology and fisheries aspects of this apparent species complex. Rev. Fish. Biol. Fish., v. 22, n. 3, p. 641-681, 2012.

WRIGHT, R. C, Miliolidea (foraminiferos) recientes del estuario del Rio Quequen Grande. Museo Argentino, de Ciencias Naturales. Hidrobiologia, v. 2, p. 225-256, 1968.

ZAR, J. H. Biostatistical analysis. 4th ed. Englewood Cliffs: Prentice-Hall, 1999. 